\title{
Linguistic Analysis of Commercial Sex Workers' Language of Negotiation
}

\author{
Doris Ogdoc-Gascon, Lilibeth D. Subayno, Tirsa Mae R. Suan, Annabelle A. Balvez, and Anna Marie P. \\ Lumacang
}

\begin{abstract}
Language has been used for many reasons, and one of which is for negotiation. Commercial sex workers have employed language that is distinct and rhetorical for negotiation purposes. Moral concern may be posed in the investigation of these workers' language of negotiation, but the promotion of sex commerce is not the aim of the study. The goal of this study is to appreciate how linguistic features contribute to a register used by a particular group of people, specifically, the commercial sex workers in Cebu, Philippines. In extracting the meaning of their language of negotiation through processing the morphology, semantics, functions, and rhetorical devices, this study offers a way of understanding this marginal and despised group in the Philippine context.
\end{abstract}

Index Terms - Commercial sex workers, connotation through images, functions of language, language of negotiation, linguistic analysis, morphologic analysis, rhetorical devices.

\section{INTRODUCTION}

The native Filipino language before the Spaniards came to the country in 1521 is of Malayo-polynesian and Arabic in origin. The earliest group of Indonesians traveled to the Philippines around 5,000 to 6,000 years ago and made another voyage around 1500 B.C. The similarities in the Filipino language and Bahasa Indonesia become proof the language acculturation. Moreover, the Malays have contributed to a huge percentage in the Philippine population [1]. When Spaniards came, there was a loaning of words from Spanish. Long period of contact with foreigners results into language borrowing. The Philippines has encountered various foreign colonizers in the period of history but no one beats the length of time the Spanish colonizers had come in contact with Filipinos. More than three hundred years, from 1500s to 1800s, the Spaniards had influenced the Filipinos in their beliefs, attitude, and culture. One aspect of culture of a group of people that the foreign colonizers have taken influence of is their language [2].

The Philippine language has evolved with the time. Technology has brought influences to the development of new vocabulary or lexicons among the Filipinos. Television personalities have made an impact to the rise of coined words [3]. The case of "borrowing" from the English language [4] and the emergence of "gay lingos" [5] have definitely introduced words of the modern age in the Philippines. Cebu, one of the popular cities of the Philippines has adapted to the trend of using new words that contribute to the richness of the

Manuscript received October 5, 2015; revised December 14, 2015.

The authors are with the Cebu Technological University, Cebu, Philippines (e-mail: doris_ogdoc@yahoo.com). country's vocabulary as well as culture [6].

Cebu is one of the most in numbers of commercial sex workers in Asia [7]. According to Abedesco of the Visayan Forum Foundation, Cebu continues to be the target, supplier and shipment region for sex trafficking, where women workers are carried to be oriented before being sent off to other places [8]. This commerce has developed commercial sex workers' expressions in their negotiation processes. These expressions have functions and purposes for persuasion. It is said that an effective speaker employs different techniques and words that are appropriate in a specific context [9].

To understand the language of a group is to understand the kind of life that they are in [10]. This study shows the language features that have aided in the dealings of the commercial sex workers with their customers. Consequently, this study gives an insight on the implications of the words used in the commercial sex workers' negotiations.

\section{OBJECTIVES}

The goal of this research is to put into record and analyze linguistically the language of negotiation of the commercial sex workers in Cebu, Philippines.

Specifically, it processes the following: 1 . the expressions of negotiation and their classification; 2. their morphology and semantics; 3. their functions; and 4. their rhetorical devices.

This research assumes that linguistic processes, language functions and rhetorical devices categorically facilitate the consummation of language of negotiation among commercial sex workers.

This research assumption is supported by Yule's English Word Formation Theory, Jakobson's Functions of Language, and Aristotle's Rhetorical Theory. Yule described the 'word formation processes' as the investigation of the steps on how new expressions evolve as a language. These developments expand the array of terms, thereby generating new lexicons [11]. Jakobson's functions of language proposition recognizes certain essentials for the facilitation of communication. These essentials are the following: the context, the addresser or the sender, the addressee or the receiver, the contact, the common code, and the message. Each factor is the focal point of a relation, or function that operates between the message and the factor. The functions are: referential, emotive, conative, phatic, poetic, and metalingual [12]. Rhetorical theory focuses on the techniques of using language effectively and persuasively in spoken form [13]. Rhetorical theory is originally developed by Aristotle which he defines as means of persuasion. Rhetoric then, is the 
study of how audiences are affected by emotion and reason in the character of the speaker. Rhetoric evaluates a speech according to how effectively a speaker in a certain opinion or information to an audience is either one person or group of a certain situation.

\section{LINGUISTIC RESEARCH METHODOLOGY}

\section{A. Method Used}

This research utilizes the qualitative research method in data-gathering and the structural analysis of conversations using the word formation processes, functions of language, and rhetoric analysis for interpreting data.

\section{B. Sources of Verbal Data}

The sources of verbal data come through referral, having twenty (20) commercial sex workers in Cebu City agree to have their conversations during negotiations with their customers recorded. Before conducting the study, a consent letter is kept confidentially under lock and keys.

\section{Data-Gathering Procedure}

This study includes three phases: (1) identifying and classifying the expressions of negotiation, (2) processing their morphology and semantics, (3) determining their functions, and (4) distinguishing their rhetorical devices.

Phase One. Identifying and classifying the expressions of negotiations. In identifying the expressions of negotiation, common terms that emerge in the twenty (20) conversations between the commercial sex workers and their customers are collated. They are classified based on the meaning and purpose in the conversations.

Phase Two. Processing the Morphology and Semantics. Expressions of negotiation are described linguistically in their word formation processes well as their semantics or meaning. Word formation can be through: affixation, compounding, symbolism (or morpheme internal change), suppletion, reduplication, acronymy, clipping (back clipping, fore clipping, middle clipping, complex clipping), blending, borrowing, back-formation, word coinage, functional shift, conversion, and derivation [14].

It is noteworthy to include the study of the morphological process of gay lingos. Most gay lingos include simple reversal of the letters/sounds within the word (otad for dato (rich), yohak for kahoy (tree), yamag for gamay (small)). Another morphological process in the formation of terminologies in gays' spoken discourse is clipping with affixation (kikiro from lalaki (guy) with the addition of "kiro") Moreover, word coinages from the connotation of images are also evident in gay lingos (Chaka which means ugly is from the popular Chaka doll in a Filipino horror movie) [15]. Semantic descriptions are providing meaning of the language, including its connotation through the images used.

Phase Three. Determining the Functions of Language. This phase involves determining the functions of language as defined by Jakobson: referential, expressive, conative, phatic, metalingual and poetic functions [16].

Phase Four: Distinguishing their Rhetorical Devices. Language of negotiation contains rhetoric. Rhetoric or the art of using speech for persuasion uses rhetorical devices such as simile, metaphor, personification, hyperbole, irony, oxymoron, and euphemism [17]. This phase distinguishes the various rhetorical devices employed in the language of negotiation of the commercial sex workers.

\section{FINDINGS}

The conversations during negotiations among commercial sex workers in Cebu are in print. However, to summarize and classify the expressions, Tables I-VI present these data.

\begin{tabular}{|c|c|c|c|c|}
\hline Expressions & Description & $\begin{array}{c}\text { Word } \\
\text { Formation } \\
\text { Process }\end{array}$ & $\begin{array}{c}\text { Denotation/ } \\
\text { Literal } \\
\text { Translation }\end{array}$ & $\begin{array}{c}\text { Connotation/ } \\
\text { Contextual } \\
\text { Meaning }\end{array}$ \\
\hline Pampa-init & $\begin{array}{c}\text { (pampa-) Init } \\
\text { - "hot" }\end{array}$ & $\begin{array}{l}\text { (Cebuano) } \\
\text { Affixation }\end{array}$ & $\begin{array}{c}\text { for a hot } \\
\text { liquid } \\
\text { (especially } \\
\text { during } \\
\text { breakfast) }\end{array}$ & \multirow{2}{*}{$\begin{array}{l}\text { To plead for } \\
\text { customers to } \\
\text { take the } \\
\text { worker so the } \\
\text { later can have } \\
\text { a hot drink or } \\
\text { coffee } \\
\text { (common } \\
\text { drinks for } \\
\text { breakfast } \\
\text { among } \\
\text { Cebuanos) }\end{array}$} \\
\hline Pang-kape & $\begin{array}{l}\text { (pang-) Kape } \\
\text { (coffee) }\end{array}$ & $\begin{array}{l}\text { (Cebuano) } \\
\text { Affixation }\end{array}$ & for coffee & \\
\hline $\begin{array}{c}\text { Pang- } \\
\text { panihapon }\end{array}$ & $\begin{array}{l}\text { (pang-) } \\
\text { panihapon } \\
\text { (dinner) }\end{array}$ & $\begin{array}{l}\text { (Cebuano) } \\
\text { Affixation }\end{array}$ & for dinner & $\begin{array}{l}\text { To plead for } \\
\text { customers to } \\
\text { take the } \\
\text { worker so the } \\
\text { later can have } \\
\text { dinner. }\end{array}$ \\
\hline $\begin{array}{l}\text { Pang- } \\
\text { tagay }\end{array}$ & $\begin{array}{l}\text { (pang-) tagay } \\
\text { (a shot) }\end{array}$ & $\begin{array}{l}\text { (Cebuano) } \\
\text { Affixation }\end{array}$ & $\begin{array}{l}\text { a shot; to } \\
\text { drink beer }\end{array}$ & $\begin{array}{l}\text { To plead for } \\
\text { customers to } \\
\text { take the } \\
\text { worker so the } \\
\text { later can have } \\
\text { a beer }\end{array}$ \\
\hline$M o$ walk $k a$ & $\begin{array}{c}\text { From the } \\
\text { borrowed } \\
\text { word 'walk' } \\
\text { means to take } \\
\text { a step }\end{array}$ & Borrowing & $\begin{array}{l}\text { Would you } \\
\text { "walk"? }\end{array}$ & $\begin{array}{l}\text { To ask if one } \\
\text { offers sexual } \\
\text { service }\end{array}$ \\
\hline Mo go ka & $\begin{array}{l}\text { From the } \\
\text { word 'go', } \\
\text { meaning to } \\
\text { proceed }\end{array}$ & Borrowing & $\begin{array}{c}\text { Would you } \\
\text { "go"? }\end{array}$ & $\begin{array}{l}\text { To ask if one } \\
\text { agrees with } \\
\text { having sex }\end{array}$ \\
\hline$P a$ job $k a$ & $\begin{array}{c}\text { (pa-) Job } \\
\text { (short for } \\
\text { "Blowjob" } \\
\text {-ka }\end{array}$ & $\begin{array}{c}\text { Borrowing } \\
\text { Fore } \\
\text { Clipping }\end{array}$ & $\begin{array}{l}\text { Would you } \\
\text { want a } \\
\text { "blowjob"? }\end{array}$ & $\begin{array}{l}\text { To ask the } \\
\text { customer if he } \\
\text { would want } \\
\text { "blowjob" } \\
\text { (oral sex) }\end{array}$ \\
\hline Fishing & Fish (+ing) & $\begin{array}{c}\text { Borrowing } \\
\text { Affixation } \\
\text { Word } \\
\text { Coinage } \\
\text { (Connotati } \\
\text { on through } \\
\text { images) }\end{array}$ & & $\begin{array}{l}\text { To find } \\
\text { customers for } \\
\text { sexual } \\
\text { services, a } \\
\text { resemblance } \\
\text { of the act of } \\
\text { "fishing". }\end{array}$ \\
\hline Gora & $\begin{array}{l}\text { from the root } \\
\text { word go }(+ \text { ra) }\end{array}$ & $\begin{array}{l}\text { Borrowing } \\
\text { Affixation }\end{array}$ & & $\begin{array}{c}\text { To "go" for } \\
\text { sexual } \\
\text { service }\end{array}$ \\
\hline
\end{tabular}

Expressions and their Classifications. Forty (46) expressions are revealed in the actual conversations of the twenty commercial sex workers in the negotiation process. 
These expressions are categorized into: Introduction Signals, Commercial Sex Workers, Money Signals, Name Substitutions, Contraceptives, and Sexual Services.

Introduction signals are the expressions used in the beginning part in most of their conversations. The second category consists of expressions that refer to commercial sex workers. Under the "Money" category, these are the expressions to identify the cost of the service rendered. "Name substitutions" are words that are used for another word. Expressions for contraceptives and sexual activities are also identified during the negotiation process.

Introductory signals of commercial sex workers include appeals to customers so that the commercial sex workers have something to drink or eat. This means that they are desperate, and that they are willing to be paid at a cheap price. Other signals for introduction would include asking the customers using codes rather than directly asking them for sex.

\begin{tabular}{|c|c|c|c|c|}
\hline Expressions & Description & $\begin{array}{c}\text { Word } \\
\text { Formation } \\
\text { Process }\end{array}$ & $\begin{array}{l}\text { Denotation/ } \\
\text { Literal } \\
\text { Translation }\end{array}$ & $\begin{array}{c}\text { Connotation } \\
\text { / } \\
\text { Contextual } \\
\text { Meaning } \\
\end{array}$ \\
\hline Harbat & & $\begin{array}{c}\text { Word Coinage } \\
\text { (Connotation } \\
\text { through } \\
\text { images) } \\
\end{array}$ & $\begin{array}{l}\text { a stolen good } \\
\text { or property }\end{array}$ & $\begin{array}{l}\text { commercial } \\
\text { sex worker; a } \\
\text { resemblance } \\
\text { of a property }\end{array}$ \\
\hline $\begin{array}{l}\text { Maria } \\
\text { Ozawa }\end{array}$ & & $\begin{array}{l}\text { Word Coinage } \\
\text { (Connotation } \\
\text { through } \\
\text { images) }\end{array}$ & $\begin{array}{c}\text { Japanese } \\
\text { porn star } \\
\text { named Maria } \\
\text { Ozawa. }\end{array}$ & $\begin{array}{l}\text { commercial } \\
\text { sex worker } \\
\text { with wide } \\
\text { sexual } \\
\text { experience } \\
\end{array}$ \\
\hline Virgin Mary & & $\begin{array}{l}\text { Word Coinage } \\
\text { (Connotation } \\
\text { through } \\
\text { images) } \\
\end{array}$ & $\begin{array}{l}\text { Virgin Mary, } \\
\text { the mother of } \\
\text { Jesus }\end{array}$ & $\begin{array}{l}\text { commercial } \\
\text { sex worker } \\
\text { with no } \\
\text { sexual } \\
\text { experience }\end{array}$ \\
\hline Taki & $\begin{array}{l}\text { Takirob is } \\
\text { from the } \\
\text { reversed } \\
\text { word for } \\
\text { "Borikat } \\
\text { "meaning a } \\
\text { sex worker } \\
\text { or } \\
\text { prostitute. } \\
\text { Takirob is } \\
\text { clipped } \\
\text { into "taki" }\end{array}$ & $\begin{array}{c}\text { Simple } \\
\text { Reversal } \\
\\
\text { Back } \\
\text { Clipping }\end{array}$ & & $\begin{array}{l}\text { commercial } \\
\text { sex worker }\end{array}$ \\
\hline Taxi horse & $\begin{array}{l}\text { Taxi (from } \\
\text { "taki") } \\
\text { Taxi horse } \\
\text { is a } \\
\text { compound } \\
\text { word from } \\
\text { taxi and } \\
\text { horse }\end{array}$ & $\begin{array}{l}\text { Compounding } \\
\text { Phonologic } \\
\text { association } \\
\text { (from the } \\
\text { word, "taki") }\end{array}$ & & $\begin{array}{l}\text { commercial } \\
\text { sex worker }\end{array}$ \\
\hline Mangga & $\begin{array}{l}\text { A clipped } \\
\text { word for } \\
\text { manggamit } \\
\text { (user) } \\
\text { (mangga+) } \\
\text { gamit (use) }\end{array}$ & $\begin{array}{c}\text { Back } \\
\text { Clipping }\end{array}$ & $\begin{array}{c}\text { From the } \\
\text { word, "user" }\end{array}$ & $\begin{array}{l}\text { commercial } \\
\text { sex worker }\end{array}$ \\
\hline
\end{tabular}

Words have been formed to connote commercial sex workers. These words are used instead of the straightforward terms such as "commercial sex workers" or "prostitutes". In the Philippines, prostitution is not legal; this is referred to in the "Anti-Prostitution Act" (Senate Bill No. 2341). The workers have to use codes to avoid being too candid.
TABLE III: EXPRESSIONS FOR MONEY SIGNALS

\begin{tabular}{|c|c|c|c|c|}
\hline Expressions & Description & $\begin{array}{c}\text { Word } \\
\text { Formation } \\
\text { Process }\end{array}$ & $\begin{array}{c}\text { Denotation/ } \\
\text { Literal } \\
\text { Translation }\end{array}$ & $\begin{array}{c}\text { Connotation/ } \\
\text { Contextual } \\
\text { Meaning }\end{array}$ \\
\hline Tokyaw & $\begin{array}{l}\text { Two thousand } \\
\text { clipped into } \\
\text { "to" and the } \\
\text { word } \\
\text { "pakyaw" } \\
\text { (wholesale) } \\
\text { clipped into } \\
\text { "kyaw". To } \\
\text { and kyaw are } \\
\text { blended to } \\
\text { form tokyaw }\end{array}$ & $\begin{array}{l}\text { Complex } \\
\text { Clipping } \\
\text { Blending } \\
\text { Borrowing }\end{array}$ & $\begin{array}{l}\text { Two } \\
\text { thousand } \\
\text { pesos (to-) } \\
\text { wholesale } \\
\text { (-kyaw) }\end{array}$ & $\begin{array}{l}\text { To provide all } \\
\text { kinds of sexual } \\
\text { services for } \\
\text { two thousand } \\
\text { pesos. }\end{array}$ \\
\hline Wantaw & $\begin{array}{l}\text { "Wan" (from } \\
\text { the English, } \\
\text { 'One'), } \\
\text { "Taw" (from } \\
\text { the English, } \\
\text { 'Thousand', } \\
\text { Clipped) }\end{array}$ & $\begin{array}{c}\text { Borrowing } \\
\text { Back } \\
\text { Clipping }\end{array}$ & $\begin{array}{l}\text { One } \\
\text { thousand } \\
\text { pesos } \\
\text { (clipped to } \\
\text { 'Wantaw') }\end{array}$ & $\begin{array}{c}\text { One thousand } \\
\text { pesos }\end{array}$ \\
\hline Dadels & $\begin{array}{l}\text { Da (clipped } \\
\text { word of } \\
\text { "datong", } \\
\text { meaning } \\
\text { cash) added } \\
\text { by a suffix } \\
\text { "dels" }\end{array}$ & $\begin{array}{c}\text { Back } \\
\text { Clipping } \\
\text { Affixation }\end{array}$ & Cash & $\begin{array}{l}\text { Payment for } \\
\text { sex }\end{array}$ \\
\hline $\begin{array}{c}\text { Two K }(2 \mathrm{~K}) \\
\text { or One } \mathrm{K} \\
(1 \mathrm{~K})\end{array}$ & $\begin{array}{l}2 \underline{\mathrm{K}} \text { (which } \\
\text { means } \\
\text { thousand) }\end{array}$ & Borrowing & $\begin{array}{c}\text { Two } \\
\text { Thousand } \\
\text { Pesos (2K) } \\
\text { One } \\
\text { Thousand } \\
\text { Pesos }(1 \mathrm{~K})\end{array}$ & $\begin{array}{c}\text { One thousand } \\
\text { pesos }(1 \mathrm{~K}) \text { or } \\
\text { Two thousand } \\
\text { pesos }(2 \mathrm{~K}) \text { as } \\
\text { payment for } \\
\text { sex }\end{array}$ \\
\hline Catching & $\begin{array}{l}\text { Catch + suffix } \\
\text { "ing" } \\
\text { catch (sounds } \\
\text { like "cash") }\end{array}$ & $\begin{array}{l}\text { Phonologic } \\
\text { association } \\
\text { (from the } \\
\text { word } \\
\text { "cash") } \\
\text { Borrowing } \\
\text { Affixation }\end{array}$ & Cash & $\begin{array}{l}\text { Cost for sexual } \\
\text { service }\end{array}$ \\
\hline
\end{tabular}

Commercial sex workers have invented words that would mean 'money'. There is an apparent need for payment for the commercial sex workers' service. The invention of these money signals may reduce the implication that they have actually done sexual activities for money.

Expressions have been used by commercial sex workers to create alluring effects. The images of heaven and celestial objects have been employed to connote the pleasure of sexual exchanges.

The expressions for contraceptives are borrowed from the American terms "condom" and its slang word, "sock" [18]. The reversal of 'condom' (mondoc) shows the influence of gay lingo in the expressions of commercial sex workers.

Expressions for sexual activities are commonly borrowed from Americans. There are other word coinages that are formed based on the images they connote, such as "mangadyi" or "to pray" which would connote the act of doing oral sex.

The commercial sex workers' language of negotiation has undergone the morphologic and semantic analyses as presented in the tables. Word formation processes, such as word coinage (connotation through images), affixation, borrowing, simple reversal, back clipping, fore clipping, complex clipping, acronymy, blending, and compounding are used. 
TABLE IV: EXPRESSIONS AS NAME SUBSTITUTIONS

\begin{tabular}{|c|c|c|c|c|}
\hline Expressions & Description & $\begin{array}{c}\text { Word } \\
\text { Formation } \\
\text { Process } \\
\end{array}$ & $\begin{array}{c}\text { Denotation/ } \\
\text { Literal } \\
\text { Translation } \\
\end{array}$ & $\begin{array}{c}\text { Connotation/ } \\
\text { Contextual } \\
\text { Meaning } \\
\end{array}$ \\
\hline Cherry Pie & & $\begin{array}{c}\text { Word } \\
\text { Coinage } \\
\text { (Connotation } \\
\text { through images) }\end{array}$ & $\begin{array}{c}\text { A sweet } \\
\text { delicious } \\
\text { sweet fruit } \\
\text { having } \\
\text { variable color } \\
\text { and a } \\
\text { moderate red. }\end{array}$ & $\begin{array}{c}\text { A virgin (a } \\
\text { woman without } \\
\text { sexual } \\
\text { experience) 's } \\
\text { vagina }\end{array}$ \\
\hline Bitoon & & $\begin{array}{l}\text { Word } \\
\text { Coinage } \\
\text { (Connotation } \\
\text { through } \\
\text { image) }\end{array}$ & Star & $\begin{array}{c}\text { A female sex } \\
\text { organ. Since stars } \\
\text { are delightful, the } \\
\text { vagina resembles } \\
\text { the signification } \\
\text { of something } \\
\text { lovely. }\end{array}$ \\
\hline Hotdog & . & $\begin{array}{c}\text { Word } \\
\text { Coinage } \\
\text { (Connotation } \\
\text { through } \\
\text { image) } \\
\text { Borrowing }\end{array}$ & & $\begin{array}{l}\text { The penis or the } \\
\text { male sex organ } \\
\text { since the image of } \\
\text { a hotdog } \\
\text { resembles the } \\
\text { image of a penis. }\end{array}$ \\
\hline Moon & & $\begin{array}{l}\text { Word } \\
\text { Coinage } \\
\text { (Connotation } \\
\text { through } \\
\text { image) } \\
\text { Borrowing }\end{array}$ & & $\begin{array}{c}\text { Pleasurable } \\
\text { moment. } \\
\text { The moon is the } \\
\text { easiest celestial } \\
\text { object to find in } \\
\text { the night sky; so it } \\
\text { connotes } \\
\text { delightful } \\
\text { experience. }\end{array}$ \\
\hline Langit & & $\begin{array}{l}\text { Word } \\
\text { Coinage } \\
\text { (Connotation } \\
\text { through } \\
\text { image) }\end{array}$ & Heaven & $\begin{array}{c}\text { Pleasurable } \\
\text { moment. Heaven } \\
\text { is a connotative } \\
\text { for a place where } \\
\text { everything is } \\
\text { wonderful and } \\
\text { every desire and } \\
\text { need is met. }\end{array}$ \\
\hline Yellow card & & & $\begin{array}{l}\text { Health } \\
\text { clearance } \\
\text { certificate }\end{array}$ & $\begin{array}{l}\text { A certificate that } \\
\text { the commercial } \\
\text { sex worker does } \\
\text { not have any } \\
\text { sexual illness, or } \\
\text { is "safe" }\end{array}$ \\
\hline Tip & & Borrowing & & $\begin{array}{l}\text { Extra money given } \\
\text { to a commercial } \\
\text { sex worker for the } \\
\text { exceptional } \\
\text { service }\end{array}$ \\
\hline Talib & $\begin{array}{l}\text { A reversed } \\
\text { word for } \\
\text { "bilat" } \\
\text { (vagina) }\end{array}$ & $\begin{array}{c}\text { Simple } \\
\text { Reversal }\end{array}$ & vagina & $\begin{array}{c}\text { vagina or the } \\
\text { female sex organ }\end{array}$ \\
\hline QL & $\begin{array}{l}\text { An acronym } \\
\text { for Queens } \\
\text { Land }\end{array}$ & Acronomy & $\begin{array}{l}\text { Queens Land } \\
\text { (a lodging } \\
\text { house in } \\
\text { Cebu) }\end{array}$ & $\begin{array}{l}\text { QL (from Queens } \\
\text { Land) is the name } \\
\text { of a popular and } \\
\text { affordable } \\
\text { lodging house in } \\
\text { Cebu. }\end{array}$ \\
\hline $\begin{array}{l}\text { lugar nga } \\
\text { mabugnaw }\end{array}$ & & $\begin{array}{c}\text { Word } \\
\text { Coinage } \\
\text { (Connotation } \\
\text { through } \\
\text { image) } \\
\end{array}$ & cold place & place to have sex \\
\hline Rounds & \begin{tabular}{|c|} 
usually \\
associated \\
with "boxing \\
rounds"; \\
rounds (a \\
series of \\
similar \\
actions, \\
events, or \\
things)
\end{tabular} & $\begin{array}{l}\text { Word } \\
\text { Coinage } \\
\text { (Connotation } \\
\text { through } \\
\text { image) } \\
\text { Borrowing }\end{array}$ & & $\begin{array}{l}\text { Number of times } \\
\text { the sexual activity } \\
\text { is consumed. }\end{array}$ \\
\hline
\end{tabular}

TABLE V: EXPRESSIONS FOR CONTRACEPTIVES

\begin{tabular}{|c|c|c|c|c|}
\hline Expressions & Description & $\begin{array}{c}\text { Word } \\
\text { Formation } \\
\text { Process }\end{array}$ & $\begin{array}{c}\text { Denotation/ } \\
\text { Literal } \\
\text { Translation }\end{array}$ & Meaning \\
\hline Modnoc & $\begin{array}{l}\text { A reversed } \\
\text { word for } \\
\text { condom }\end{array}$ & $\begin{array}{c}\text { Simple } \\
\text { Reversal } \\
\text { Borrowing }\end{array}$ & condom & $\begin{array}{c}\text { A kind of } \\
\text { contraceptio } \\
\mathrm{n} \text { specifically } \\
\text { a condom } \\
\text { inserted into } \\
\text { a penis } \\
\text { during sexual } \\
\text { intercourse to } \\
\text { prevent } \\
\text { pregnancy } \\
\text { and HIV. } \\
\end{array}$ \\
\hline Medyas & $\begin{array}{c}\text { medyas } \\
\text { (sock) }\end{array}$ & $\begin{array}{c}\text { Word } \\
\text { Coinage } \\
\text { (Connotation } \\
\text { through } \\
\text { image) }\end{array}$ & $\begin{array}{c}\text { sock (means a } \\
\text { short stocking } \\
\text { usually } \\
\text { reaching to the } \\
\text { calf or just } \\
\text { above the } \\
\text { ankle) }\end{array}$ & $\begin{array}{l}\text { Condom. } \\
\text { The image of } \\
\text { the condom } \\
\text { is like that of } \\
\text { the sock. }\end{array}$ \\
\hline
\end{tabular}

\begin{tabular}{|c|c|c|c|c|}
\hline Expressions & Description & $\begin{array}{c}\text { Word } \\
\text { Formation } \\
\text { Process }\end{array}$ & $\begin{array}{c}\text { Denotation/ } \\
\text { Literal } \\
\text { Translation }\end{array}$ & Meaning \\
\hline Skin to skin & & Borrowing & & $\begin{array}{l}\text { No use of } \\
\text { condom during } \\
\text { sexual } \\
\text { intercourse } \\
\text { (because } \\
\text { condoms may } \\
\text { reduce the } \\
\text { pleasure) }\end{array}$ \\
\hline P.R. & $\begin{array}{l}\text { Acronym } \\
\text { for personal } \\
\text { relation }\end{array}$ & $\begin{array}{l}\text { Borrowing } \\
\text { Acronym }\end{array}$ & & $\begin{array}{l}\text { To "escort" or } \\
\text { accompany } \\
\text { customers for } \\
\text { social purposes }\end{array}$ \\
\hline Blow Job/Job & & Borrowing & & $\begin{array}{c}\text { The act of } \\
\text { bobbing the } \\
\text { male sex organ; } \\
\text { oral sex }\end{array}$ \\
\hline Mangadyi & $\begin{array}{l}\text { (mang-) } \\
\text { "adyi”, from } \\
\text { pangadyi } \\
\text { (pray) }\end{array}$ & $\begin{array}{l}\text { Word Coinage } \\
\text { (Connotation } \\
\text { through } \\
\text { image) } \\
\text { (Cebuano) } \\
\text { Affixation }\end{array}$ & to pray & $\begin{array}{l}\text { To do oral sex } \\
\text { on the male } \\
\text { customer, since } \\
\text { the image of } \\
\text { performing oral } \\
\text { sex on men } \\
\text { resembles } \\
\text { praying: } \\
\text { kneeling down } \\
\text { while } \\
\text { performing the } \\
\text { ritual }\end{array}$ \\
\hline Suyop & & $\begin{array}{l}\text { Word Coinage } \\
\text { (Connotation } \\
\text { through } \\
\text { Image) }\end{array}$ & to suck & $\begin{array}{l}\text { To do oral sex } \\
\text { or "blowjob" }\end{array}$ \\
\hline $\begin{array}{l}\text { One night } \\
\text { stand }\end{array}$ & & Borrowing & & $\begin{array}{l}\text { A sexual } \\
\text { intercourse that } \\
\text { happens once. }\end{array}$ \\
\hline Quicky & $\begin{array}{c}\text { From the } \\
\text { word } \\
\text { "quick" } \\
\text { means } \\
\text { hurried or a } \\
\text { hurried sex }\end{array}$ & Borrowing & & $\begin{array}{c}\text { A short and fast } \\
\text { sexual } \\
\text { intercourse. }\end{array}$ \\
\hline Service & & Borrowing & & Sex service \\
\hline Tira & $\begin{array}{l}\text { A Visayan } \\
\text { term for } \\
\text { "shoot" } \\
\text { which } \\
\text { means to } \\
\text { strike a } \\
\text { missile ,a } \\
\text { bow or gun }\end{array}$ & $\begin{array}{l}\text { Word Coinage } \\
\text { (Connotation } \\
\text { from image) }\end{array}$ & To shoot & $\begin{array}{l}\text { Sex. } \\
\text { The inserting of } \\
\text { the penis into } \\
\text { the female sex } \\
\text { organ resembles } \\
\text { that of "tira" or } \\
\text { shooting }\end{array}$ \\
\hline
\end{tabular}




\begin{tabular}{|c|c|c|c|c|}
\hline $\begin{array}{c}\text { Magginamita } \\
y\end{array}$ & $\begin{array}{c}\text { "Gamit" } \\
\text { (use) } \\
\text { prefix } \\
\text { "mag+" } \\
\text { infix -in- + } \\
\text { suffix -ay-. }\end{array}$ & $\begin{array}{l}\text { Cebuano } \\
\text { (Affixation) }\end{array}$ & $\begin{array}{l}\text { "To use each } \\
\text { other" }\end{array}$ & $\begin{array}{c}\text { Sexual } \\
\text { intercourse }\end{array}$ \\
\hline $\begin{array}{c}\text { Take } \\
\text { Home/Take } \\
\text { Out }\end{array}$ & & Borrowing & & $\begin{array}{c}\text { To take } \\
\text { someone for sex }\end{array}$ \\
\hline Tila & $\begin{array}{l}\text { Clipped } \\
\text { word of } \\
\text { "tilap" (to } \\
\text { lick) }\end{array}$ & $\begin{array}{c}\text { Back } \\
\text { Clipping }\end{array}$ & to lick & $\begin{array}{l}\text { Licking of the } \\
\text { sex organ }\end{array}$ \\
\hline Tilaw & & $\begin{array}{c}\text { Word Coinage } \\
\text { (connotation } \\
\text { through } \\
\text { image) } \\
\end{array}$ & to taste & $\begin{array}{l}\text { To experience } \\
\text { sexual } \\
\text { intercourse for } \\
\text { the first time. }\end{array}$ \\
\hline
\end{tabular}

Functions of language. The functions of language are mostly metalingual and phatic. The metalingual function is the use of code to discuss or describe itself. It establishes mutual agreement on the code and provides an explanation to have a clearer interaction by the addressee [19]. Examples from the sentences derived from the conversations are: Naa $k o ' y$ hotdog diri (I have a hotdog here; hotdog - to codify the male sex organ); Wala na'y uso Virgin Mary sir oy (Virgin Mary is not the trend now, sir; Virgin Mary - to codify "Virgins" or those without sexual experience). Phatic function is employed with the channel aspect. It is a remark to greet and initiate informal conversations which is a key to unfasten, keep up, or end the exchange of words [20]. Some examples of this function are found in the conversations: "Miga! Mo walk ka?" (Girl friend! Would you "walk"?; to walk means to offer sex); "Sir, Mo go ka?" Sir, would you "go"?; to go means to proceed with the sex service).

Rhetorical devices. The rhetorical devices used among the commercial sex workers' language of negotiation are mostly euphemism and metaphor. Euphemism is word to replace an offensive or unlikeable expression. Its etymology reveals that the prefix, "eu", stands for 'pleasant to hear', the root, "pheme" indicates " to speak", and the suffix "ism" denotes an 'act or response' [17]. An example of euphemism is in the following line: Pwedi tika ma take out? (Can I have you as "take out"?; this expression would ask for the sexual service of the commercial sex worker). Metaphor is an implied comparison without like, as, than, or seem [17]. Metaphor is used as a rhetorical device in the line: Makabusog man kaha $n a ' g$ siyam ka bitoon imu hotdog? (Will your hotdog satisfy the hunger of nine stars?; hotdog is compared to the male sex organ, the stars are compared to the female sex organs).

\section{CONCLUSION}

The linguistic processes, language functions and rhetorical devices categorically facilitate the consummation of the language of negotiation among commercial sex workers. The formation of words and expressions through these processes, functions, and rhetorical style has made a distinct mark of the modern Filipino language.

The uniqueness of the Filipino language has now been established with the emergence of these new expressions. These expressions are influenced by the society that the Filipinos nowadays are living in. With the commercial sex workers' language of negotiation, it can be gleaned that the words have been influenced from the borrowing of the American English language. The evolution has come this far from the Bahasa language to the Spanish loaned words, and now, to the American English lexical as well as cultural influence.

This linguistic study on a language of a certain group of the Philippines must be imparted to those academics handling courses in linguistics and social studies. Further studies on the processes of new Filipino terms are recommended to support the artistry of the contemporary Filipinos.

\section{ACKNOWLEDGMENT}

The author wishes to extend her gratitude to the following academics in language who have reviewed and made suggestions on this research: Dr. Edwin A. Pilapil and Dr. Imelda J. Villarin. In addition, she is grateful to International Conference on Languages, Literature and Linguistics-ICLLL 2014 for the reviews and comments that have polished this research work.

\section{REFERENCES}

[1] V. Bautista, The Philippines: Then and Now, Excerpted from The Filipino Americans (From 1763 to the Present): Their History, Culture, and Traditions, 2007.

[2] D. Ogdoc, "Spanish loan-words in Cebuano-Visayan," Cebu Normal University, 2013.

[3] J. G. U. Rubrico, The Metamorphosis of Filipino as National Language, Language Links, 2015.

[4] M. E. Atienza, "Ang pulitika sa paggawa ng palisi ng wika," in $M g a$ Piling Diskurso sa Wika at Lipunan, Constantino and Atienza, Eds. Quezon City: UP Press, 1996, pp. 133-156.

[5] R. A. Alba, In Focus: The Filipino Gayspeak (Filipino Gay Lingo), National Commission for the Culture and the Arts, Republic of the Philippines, February 26, 2015.

[6] D. Hart and H. Hart, "Visayan Swardspeak: The Language of a Gay Community in the Philippines," Crossroads: An Interdisciplinary Journal of Southeast Asian Studies, vol. 5, no. 2, pp. 27-49, 1990.

[7] L. Law, Sex Work in Southeast Asia: The Place of Desire in a Time of a AIDS, London: Routledge Pacific Rim Geographies, 2000, p. 29.

[8] M. B. A. Parco, "Cebu a transit point for child trafficking," Philippine News for Filipinos, March 15, 2015.

[9] Persuading, Influencing and Negotiating Skills, University of Kent Careers and Employability Service, October 19, 2015.

[10] D. O'Neil. (October 24, 2006). Language and Thought Processes. [Online]. Available: http://anthro.palomar.edu/language/language_5.htm

[11] G. Yule, The Study of Language, 4th ed. New York: Cambridge University Press, 2006, p. 64.

[12] E. Armstrong, "Language, meaning, context, and functional communication," Edith Cowan University, 2011.

[13] W. Minot, Politics and Identity: Theory and Practice for Composition, Massachusetts: Winthrop Publishers Inc., 1972.

[14] L. Bauer, English Word Formation, Cambridge: Cambridge University Press, 2012.

[15] A. Lunzaga, "Morphological analysis of gay's spoken discourse," National Peer Reviewed Journal JPAIR Multidisciplinary Journal, vol. 6, May 2011.

[16] R. Jakobson, "Linguistics and Poetics," in Style in Language, T. Sebeok, Ed. Cambridge, MA: MIT Press, 1960, pp. 350-377.

[17] R. A. Harris, A Handbook of Rhetorical Devices, Virtual Salt Home, January 19, 2013.

[18] T. Dalzell, The Routledge Dictionary of Modern American Slang and Unconventional English, New York: Routledge, 2009, p. 915.

[19] L. Waugh, "The poetic function in the theory of Roman Jakobson," Poetics Today, 1980.

[20] K. Makice, "Phatics and the design of community," in Proc. the 27th International Conference Extended Abstracts on Human Factors in Computing Systems, Boston, MA, USA, 2009. 


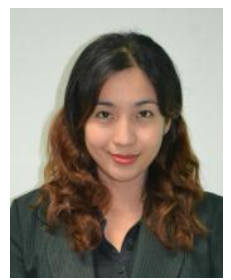

Doris Ogdoc-Gascon was born in Cebu, Philippines on November 13, 1986. She has finished her master's degree in literature in 2012, and has earned her doctorate degree in literature and communication at Cebu Normal University in March 2015. Moreover, her dissertation entitled, Doris Ogdoc-Gascon's Novelette, Yeshua in Yolanda, which is a creative work in novelette narrating the stories of the survivors of the super typhoon Haiyan of 2013, also locally called Yolanda, was awarded the Best Dissertation.

Currently, she is a university instructor at a state college in Philippines, Cebu Technological University. She is handling subjects for postgraduate studies (MA.Ed in English teaching) and undergraduate program of the bachelor of arts in English major in applied linguistics. She is also the chairperson for Publication of the Journal on Arts and Sciences of the university.

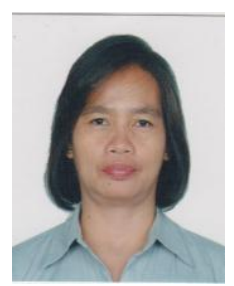

Lilibeth D. Subayno finished her AB in English, majored in applied linguistics at Cebu Technological University, Main Campus. She pursued her MA studies in the same institution after obtaining a certificate in professional education for basic education teachers. She taught in an ESL school for a term and gained experience in handling foreign students who wished to learn the English language. She is currently teaching at CTU, Main Campus, handling various English classes for almost three years.

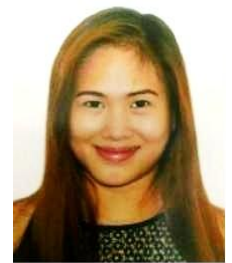

Tirsa Mae R. Suan is an AB in English candidate, majoring in applied linguistics in Cebu Technological University, Main Campus, who has made great contribution, especially in the gathering of data for this study.

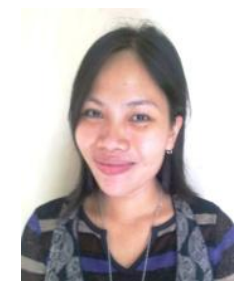

Annabelle A. Balvez is an AB in English candidate, majoring in applied linguistics in Cebu Technologica University, Main Campus, who has made great contribution, especially in the gathering of data for this study.

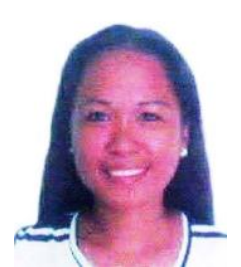

Anna Maria P. Lumacang is an $A B$ in English candidate, majoring in applied linguistics of Cebu Technological University, Main Campus, who has made great contribution, especially in the gathering of data for this study. 